\title{
Digestion
}

Ahn, S.H. 29

Ando, K. 5

Arizumi, T. 56

Chiba, T. 43

Cho, E.J. 17, 23

Choi, J.G. 35

Chung, H. 56

Chung, Y.-H. 35

El-Shamy, A. 10

Eso, Y. 43

Fujinami, A. 5, 10

Fukuda, K. 5

Hagiwara, S. 56

Han, K.-H. 29

Hasegawa, Y. 5, 10

Hayaishi, S. 56

Hayashi, Y. 5

Hotta, H. 5, 10

Imoto, S. 5, 10

Inoue, T. 56

Jang, E.S. 17, 23

Jin, Y.-J. 35

Kasugai, H. 10

Kawada, T. 10

Kim, B.K. 29

Kim, J.A. 35
Kim, K.I. 5, 10

Kim, S.E. 35

Kim, S.H. 35

Kim, S.K. 43

Kim, S.R. 5, 10

Kim, Y.J. 17, 23

Kimura, N. 10

Kimura, T. 43

Kita, R. 43

Kitai, S. 56

Komaki, T. 5, 10

Konishi, E. 10

Kudo, M. 1, 5, 10, 43, 56

Kwak, M.-S. 17, 23

Lee, D. 35

Lee, H.-S. 17, 23

Lee, J.-H. 17, 23

Lee, Y.S. 35

Maekawa, Y. 5

Makino, T. 10

Marusawa, H. 43

Minami, Y. 56

Morikawa, T. 10

Muramatsu, A. 10

Nagata, Y. 5, 10

Nakajima, T. 5, 10
Nakamura, A. 10

Nishikawa, H. 43

Ohta, M. 5, 10

Ohtani, A. 5

Osaki, Y. 43

Otono, Y. 5

Park, W.H. 35

Saito, J. 5, 10

Sakashita, M. 10

Sakurai, T. 56

Sasase, N. 10

Sasatani, K. 10

Shim, J.H. 35

Sugano, M. 10

Sugimoto, K. 5

Takita, M. 56

Tanaka, Y. 10, 50

Tsuchida, S. 10

Ueda, T. 56

Ueda, Y. 43

Ueshima, K. 56

Yada, N. 56

Yang, S.H. 35

Yoon, J.-H. 17, 23

Yu, S.J. 17, 23

\section{Subject Index Vol. 84, Suppl. 1, 2011}

Age 23

Alcohol 43

Antiviral response 35

Chronic hepatitis B 23, 29, 35

- - C 56

Complete early virological response 10

Core aa70 56

Diabetes 43

Double-filtration plasmapheresis 1,10

Drug dose 56

Etiology 17

Genome-wide association study 50

Genotype $1 \mathrm{~b} 5$

HBsAg seroclearance 23

Hepatic fibrosis 5

- steatosis 5
Hepatitis B 1

- - core antibody 17

- - e antigen 29

- $\quad$ surface antigen 29

- - virus 29

- C 1

- - virus 50

Hepatocellular carcinoma 17

High viral load 5

Human leukocyte antigen 35

Inosine triphosphatase 1,50

Insulin resistance 5

Interferon- $\beta 10$

Interferon- $\lambda 50$

Interleukin-28B 1, 50, 56

Lamivudine 35
Liver cancer 43

Nonalcoholic fatty liver disease 17

- steatohepatitis 43

Non-B non-C HCC 43

Null virological response 10

Pegylated interferon 5

_ _ plus ribavirin therapy 56

- - ribavirin therapy 1

Quantitative assay 29

Rapid virological response 10

Relapse 10

Ribavirin 5, 10

Serum HBV DNA 23

Sustained inactive phase 23

- virological response 5

Viral dynamics 10 